Article

\title{
Application of Anti-Transpirant to Control Sugar Accumulation in Grape Berries and Alcohol Degree in Wines Obtained from Thinned and Unthinned Vines of cv. Falanghina (Vitis vinifera L.)
}

\author{
Claudio Di Vaio ${ }^{1} \mathbb{D}$, Clizia Villano ${ }^{1, * \mathbb{C}}$, Maria Tiziana Lisanti ${ }^{1}$, Nadia Marallo ${ }^{1}$, \\ Aurora Cirillo ${ }^{1}$, Rosario Di Lorenzo ${ }^{2}$ and Antonino Pisciotta ${ }^{2, *(D)}$ \\ 1 Department of Agricultural Sciences, University of Naples Federico II, Via Università 100, 80055 Portici, \\ Italy; claudio.divaio@unina.it (C.D.V.); mariatiziana.lisanti@unina.it (M.T.L.); \\ nadia.marallo@hotmail.it (N.M.); aurora.cirillo@unina.it (A.C.) \\ 2 Department of Agricultural, Food and Forest Sciences (SAAF), University of Palermo, Viale delle Scienze, \\ Ed 4, 90128 Palermo, Italy; rosario.dilorenzo@unipa.it \\ * Correspondence: clizia.villano@unina.it (C.V.); antonino.pisciotta@unipa.it (A.P.); Tel.: +39-0812532611 (A.P.)
}

Received: 13 January 2020; Accepted: 27 February 2020; Published: 3 March 2020

\begin{abstract}
In the last few decades, the accumulation of sugar in grape berries and hence the alcohol degree of wines has been affected by increasing global temperatures. In order to limit plant photosynthetic activity, it is possible to apply anti-transpirant on field, reducing sugar accumulation in berries. In this contest, our aim was to evaluate the efficiency of the application of a di-1-p-menthene-based natural anti-transpirant (Vapor Gard ${ }^{\circledR}$, VG) on Falanghina vines during 2013 and 2014. Plants were treated at veraison stage with VG and compared with water-sprayed ones for control. The experimental design included also bunch thinned (BT) plants treated with VG or water. The effect of VG and/or BT on grapes was evaluated through physiological measurements on vines and chemical analyses on berries and wines. Moreover, wine sensory profiles were produced. The results we obtained show that by applying anti-transpirant it is possible to induce a significant reduction of net photosynthesis rate $(25 \%-40 \%)$ and stomatal conductance $(40 \%-60 \%)$ on leaves, a lower sugar accumulation in berries $\left(2{ }^{\circ} \mathrm{Brix}\right)$ and a consequent reduction of alcohol in the obtained wine $(0.9 \%-1.6 \%$ vol.). These results suggest that anti-transpirant sprays could be a useful tool in reducing cost of yield manipulation, improving ripeness and reducing wine alcohol, without affecting the wine sensory profile.
\end{abstract}

Keywords: grapevine; anti-transpirant; low alcohol wine; gas exchanges

\section{Introduction}

The wine industry is more and more engaged in research that aims to decrease the content of alcohol in wine, both because it has been part of the question about responsible consumption of alcoholic beverages, and because of the heightened sensitivity of customers about health issues including increased calories intake and risk from alcohol-related illness and disease [1]. A moderate alcohol content is generally defined as $8.5 \%-12 \% v / v$ alcohol and wines with this content can be obtained through several methods applied at different steps of the process, such as canopy management during grape plant life cycle to reduce fermentable sugar concentration in grape [2-6], non-Saccharomyces yeast starters usage during vinification to reduce alcoholic fermentation efficiency [7] and dealcoholisation of wine [8-10]. Beside the strategies that involve canopy management of the grapevines, there are other methods that can give results in a less amount of time, they consist in different techniques 
that is possible to consider of two distinct groups. The objective of the first one is to increase the competition between vine organs: in this case is taken into consideration a technique that sees a calculated reduction of the leaf area to the cluster ratio by operating diverse shoot trims at different phenological moments or a calculated leaf pulling close to the cluster area $[11,12]$. The objective of the second group is to artificially change the environmental conditions for the photosynthesis, which is possible, for example, by arranging shading nets so that the active radiation of the photosynthesis will be decreased, or also with the help of anti-transpirant that will be applied to the canopy in order to reduce the gas exchange rate, the ultimate aim being to slow down and diminish the amount of sugar in berries $[2,13,14]$. Concerning the use of anti-transpirants, it is possible to implement different chemicals in a variety of biological activities in order to reduce the rate of transpiration and enhance the resistance of the leaf to the dispersion of water vapour, so as to mitigate plant water stress. It is possible to identify two different kinds of anti-transpirants basing on their mechanism of action: the film-forming types and the stomatal-closing ones. In the first case, the anti-transpirant forms a thin cover on the leaf surface impeding dispersion of water in form of vapour; in the second case the non-transpirant effects the metabolic activities of the leaf tissues $[15,16]$. Film-forming types, such as kaolin and di-1-p-menthene, resulted in being not toxic and, in comparison with the metabolic ones, have a longer effectiveness. When using kaolin, an inert clay mineral, the result was an effective control of the heat stress in various species, increasing canopy reflectance of infrared and ultraviolet radiations it was possible to obtain a lower temperature of both the leaf and the fruit tissues $[13,17]$. The same happens with 1-p-menthene, [pinolene], which is an emulsifiable terpenic polymer distilled from conifer resins; when applied it creates a thin, transparent and flexible coat stopping the water dispersion as a proper physical barrier. [18]. Recently, Fahey and Rogiers [19] demonstrated that di-1- $p$-menthene decreased water loss in both the leaf and the bunch, and is effective at $30{ }^{\circ} \mathrm{C}$ and $35^{\circ} \mathrm{C}$. Furthermore, it did not cause fruit abortion (fruit drop). Nowadays, most studies dealing with the use of film-forming anti-transpirant to grape ripening have been implemented on red cultivars, such as Cabernet Sauvignon [20], Sangiovese [13,18], Barbera [21] and Aglianico [22]. To the authors' best knowledge, only Lucchetta and collaborators [2] used this technique on a white grapevine variety, Sauvignon blanc, emphasising the need to study physiological and chemical effects of antitranspirant molecules on other white grapes. The objective of this study is to assess the effect of a di-1-p-menthene based anti-transpirant (Vapor Gard ${ }^{\circledR}$, VG) on grapevine physiology and on the composition of both berry and wine of Falanghina variety. The application of VG was evaluated in comparison to bunch thinning, and the two techniques were also evaluated in association, as tools to control the accumulation of sugar. The Falanghina grapevines are characteristic of the Campania region, in southern Italy; they are recognisable by their typical middle trunk conical bunch, medium sized grapes with waxy peel and crispy pulp, giving wines with slightly floral aroma. Together with Aglianico, it represents a powerful genetic resource slightly explored [23-26].

\section{Materials and Methods}

\subsection{Experimental Site, Design and Treatment}

The experiment was conducted in the province of Benevento $\left(41^{\circ} 15^{\prime} 32^{\prime \prime} \mathrm{N}, 14^{\circ} 35^{\prime} 54^{\prime \prime} \mathrm{E}\right)$ during growing seasons 2013/2014. For the trial, a field with franco-loamy soil was chosen, positioned in an area $300 \mathrm{~m}$ above the level of the sea. The study implemented in a non-irrigated vineyard of Falanghina (white grape variety) grafted on 1103 Paulsen, in which vines were planted at $2.50 \times$ $1.40 \mathrm{~m}$ inter and intra row distance. The vines were trained to a vertical shoot position system and bilateral Guyot hand-pruned with 30 nodes per vine, 15 for each long cane. Pest management was carried out according to local standard practice. The study included a spray implementation of the anti-transpirant Vapor Gard ${ }^{\circledR}(\mathrm{VG})$ and a water spray application (Control). VG is a water emulsifiable organic concentrate of di-1- $p$-menthene $\left(\mathrm{C}_{20} \mathrm{H}_{34}\right)$, a terpenic polymer also known as pinolene. VG was prepared as a $2 \%$ solution in water and all the leaves of the canopy located above the cluster area 
were sprayed using a portable pump. The VG treatments were applied at full veraison (E-L stage 35). To half vines of VG and Control plants was applied a 30\% of bunch thinning (BT) three days before spray applications. We then compared four theses: Vapor Gard application (VG-BT), water application as Control (C-BT), VG application with BT (VG + BT) and water with BT (C + BT). In a total area of 1000 square meters with homogeneous soil characteristics, it was chosen a selection of ten vines per treatment, randomly located in the vineyard.

\subsection{Gas Exchange Measurements}

The exchanges of the gas were measured onto 10 mature leaves (10-12 node position) as reported by Di Vaio et al. [22]. Measuring of stomatal conductance (gs) was done six times, about every 12 days, after VG application, from three days after spray treatments until harvest while the measuring of assimilation (A) and transpiration (E) were carried out at harvest.

\subsection{Growth, Yield, and Grape Composition}

In order to collect the data, the samples were picked randomly, from veraison to harvest, on six different calendar days of the two considered years, in four repetitions of 50 berries, each of them consisting in five berries per ten vines. Casual order was also applied to collect the samples from the top, middle and bottom parts of the bunch both from the side exposed to the sun and the non-exposed ones, so to get data on the ripeness of the grape and evaluate the optimal harvest moment using soluble solid content as indicators of ripeness level. In both years, all grapes were harvested on the same day, when control treatments (C-BT) reached $22^{\circ}$ Brix.

The berries were weighted using a digital precision weighing scale (Acculab Sartorius Group ECON EC-411). Crushing by hand all the berries of the different series collected, it was obtained the juice used to assess the following: total soluble solids ( $\left.{ }^{\circ} \mathrm{Brix}\right), \mathrm{pH}$, and titratable acidity (TA). Total soluble solids (TSS) concentration was determined with a digital refractometer (Model L-R 01 Digital Refractometer, Maselli Misure S.p.a., 43100 Parma, Italy) on $2 \mathrm{~mL}$ of juice at $20^{\circ} \mathrm{C}$. Samples of $10 \mathrm{~mL}$ of juice were used for $\mathrm{pH}$ and TA measurements. $\mathrm{pH}$ was measured by a digital $\mathrm{pH}$ meter (Crison Instrument GLP $21 \mathrm{pH}$ ); TA was determined using the official method for TA determination, with $0.1 \mathrm{~N} \mathrm{NaOH}$ to a $\mathrm{pH} 8.2$ end-point, and was expressed as $\mathrm{g} \mathrm{L}^{-1}$ of tartaric acid, phenolic maturity was determined according to [27] and expressed as $\mathrm{mg} \mathrm{L}^{-1}$. In the moment of the harvesting were established the yield and the bunch number for each vine, during wintertime of each considered year was also assessed the pruning weight for each vine.

\subsection{Microvinification and Wine Analysis}

During the considered years for the study (2013/2014) the wines were produced by implementing a standard microvinification protocol. One hundred kilograms of fruit per treatment were manually picked during the harvesting, put in plastic boxes of $20 \mathrm{~kg}$ each and then sent to the site of the experimental winery. In order to get all the possible chances of result the bunches were harvested from both sun-exposed sides and not sun-exposed sides of the vines. It was considered to implemented two microvinifications per treatment. For each of them the grapes were pressed mechanically, destemmed and then moved to the fermentation tanks. Potassium metabisulphite was added to obtain a total $\mathrm{SO}_{2}$ level of about $35 \mathrm{mg} \mathrm{L}^{-1}$ and a commercial Saccharomyces cerevisiae strain (BCS 103 Springer Oenologie) was inoculated at $20 \mathrm{~g} \mathrm{hL}^{-1}$. Musts were fermented for 16 to 18 days on the skin and punched down twice daily, with the fermentation temperature ranging from 20 to $23{ }^{\circ} \mathrm{C}$. After alcoholic fermentation (total soluble solids $<2 \mathrm{~g} \mathrm{~L}^{-1}$ ), the wines were collected by racking at $0{ }^{\circ}$ Brix and inoculated with $30 \mathrm{~g} \mathrm{hL}^{-1}$ of Oenococcus oeni (Lalvin Elios $1 \mathrm{MBR}$; Lallemand). After completion of malolactic fermentation, the samples were racked, added with $50 \mathrm{mg} \mathrm{L}^{-1}$ of potassium metabisulphite and bottled. The wines were analysed for alcoholic strength, total acidity, $\mathrm{pH}$, and total phenols, (Wine Scan ${ }^{\mathrm{TM}}$ Auto, Hillerod, Denmark). All determinations on wines were carried out in duplicate on each replicate of microvinification, yielding four repetitions per treatment. 


\subsection{Sensory Analysis}

A sensory analysis was implemented to assess the aroma of the experimental wines. It was selected a panel of 12 judges (seven males and five females, aged 22-55 years) among experienced wine tasters, basing on their olfactory skills and trained in recognising, describing and quantifying aromas (chemical standards). The samples $(30 \mathrm{~mL})$ were presented to the judges in black tulip-shaped glasses that were coded with random three-digit codes. Each sample was served at a temperature of $10^{\circ} \mathrm{C}$ and assessed in duplicate during two different sessions. During each session every judge examined all the wines, that were presented following a random sequence. It was requested to each judge to rate the perceived intensities of seven odour descriptors, generated consensually in a previous dedicated session. Moreover, a typicality judgement was asked, corresponding to the question "How much this is a good example of Falanghina white wine, in your opinion". An 11-point structured scale, ranging from 0 to 10 , was employed.

\subsection{Statistical Analysis}

Analysis of variance (ANOVA) and mean separation by Duncan's multiple range test $(p<0.05)$ were performed using the statistical package XLStat Version 2013 (New York, NY, USA).

\section{Results and Discussion}

The capacity of effect of an anti-transpirant is assessed basing on various data: its concentration, the environment, the species and the level of growth of the plant it is implemented on [28]. In viticulture, anti-transpirants are implemented to avoid water dispersion of the plant with consequent effects on the composition of the fruit, the yield elements and in part also on the final product, wine [29]. When implemented on Cabernet Sauvignon field vines, growing in hot environment, it has been found that a kaolin-based film enhances the water conditions of the plant and intrinsic water use efficiency; however, a di-1-p-menthene based film did not give the same results [20], whereas when implementing this last one on Sangiovese, growing also in a warm environment, intrinsic water use efficiency was enhanced [13,18]; when implemented on Barbera growing in a mild climate, it was not detected any change in the immediate water use efficiency [21]. The present study represents an evaluation of the effectiveness of di-1- $p$-menthene to decrease grapevine transpiration and to enhance transpiration efficiency in cv Falanghina, grown in a warm climate.

\subsection{Gas Exchange Parameters}

The Vapor Gard ${ }^{\circledR}(\mathrm{VG})$ application at veraison significantly reduced the stomatal conductance (gs), assimilation rate (A) and transpiration rate (E) of leaves in both growing seasons, 2013 and 2014. In particular, the stomatal conductance evolved from VG application to harvest time with a constant decrease in 2013 and a variable trend in 2014 (Figure 1A,B).

These results show that the film-forming anti-transpirant is able to active a transient inhibition of leaf photosynthetic rate confirming the findings obtained on other grape cultivars, such as Sangiovese [13,14,18], Barbera [21], Sauvignon blanc [2] and Aglianico [22]. Similar results were obtained regarding the leaf assimilation rate (A). Indeed, at harvest, it was higher in the control vines compared to the treated ones in both the studied years. In particular, in 2013, 11.6 vs. $16.3 \mu \mathrm{mol}$ $\mathrm{m}^{2} \mathrm{~s}^{-1}$ for VG-BT and C-BT, respectively, were recorded, with a $29 \%$ reduction of leaf assimilation rate. Comparable results were observed in bunch thinned plants in the same year: $11.5 \mathrm{vs} .15 .4 \mu \mathrm{mol} \mathrm{m} \mathrm{m}^{-1}$ (VG + BT vs. C-BT) with a $25.3 \%$ of reduction (Figure 2A). 

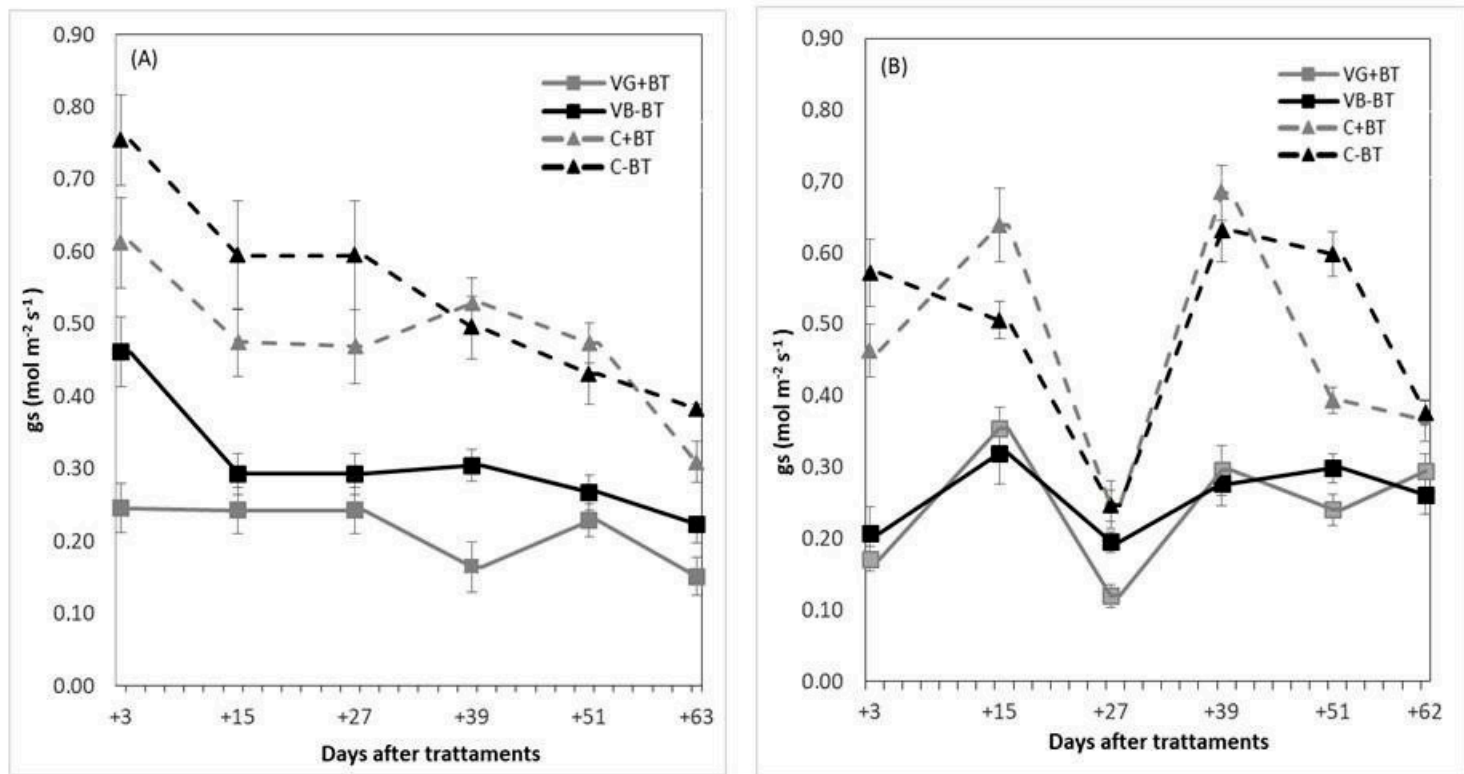

Figure 1. Stomatal conductance (gs) expressed as $\mathrm{mol} \mathrm{m}^{2} \mathrm{~s}^{-1}$ measured in control (C) and treated with Vapor Gard (VG) Falanghina vines in 2013 (A) and 2014 (B). Bunch thinned vines are reported as BT. Data are averages of 10 replicates \pm SE.
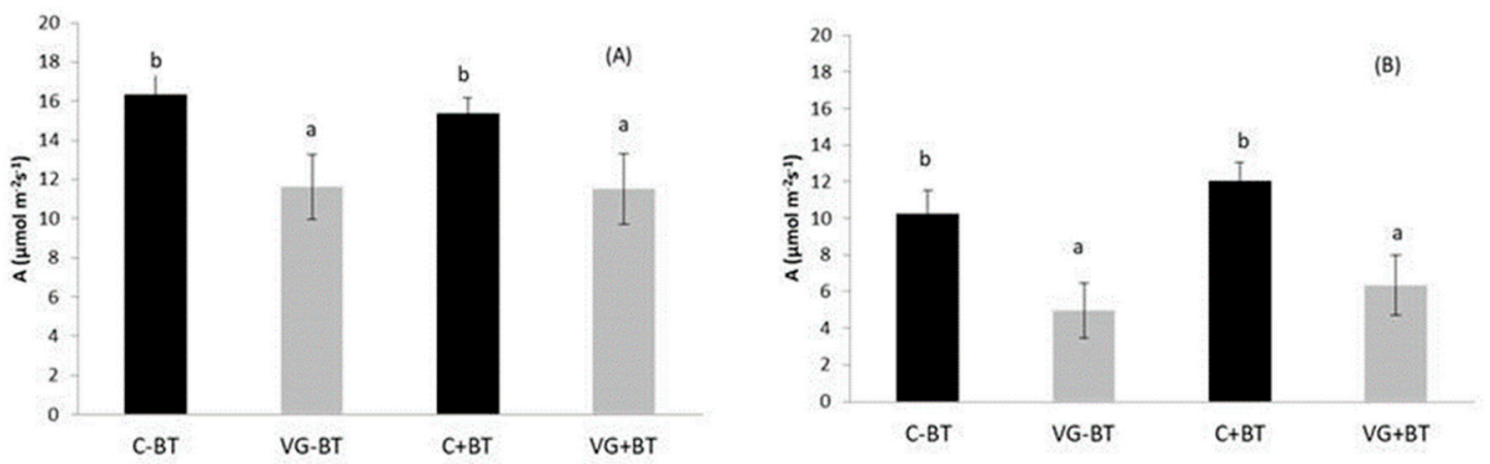

Figure 2. Assimilation rate (A) measured at harvest, in the years 2013 (A) and 2014 (B) on fully expanded Falanghina leaves sprayed with anti-transpirant Vapor Gard ${ }^{\circledR}$ (VG) at $\%$ or left unsprayed (C) with or without bunch thinning (BT). Data are averages of 10 replicates \pm SE. Same letter indicates not significant differences at Duncan post hoc test $(p<0.05)$.

In 2014, VG treatment showed an assimilation rate of $4.96 \mu \mathrm{mol} \mathrm{m} \mathrm{m}^{-1}$, while the respective control (C) recorded $10.27 \mu \mathrm{mol} \mathrm{m} \mathrm{s}^{-1}$. In the bunch thinning treatment, the results were similar: 6.34 vs. $12.04 \mu \mathrm{mol} \mathrm{m}^{2} \mathrm{~s}^{-1}$ (VG + BT vs. C + BT) (Figure 2B). In both treatments, the percentage of reduction of leaf assimilation rate was about 47.8 in percentage. As expected, in both growing seasons, this parameter was significantly affected by the anti-transpirant treatment, while no effect was recorded by bunch thinning. Our results are in accordance with [13] which showed that, after VG application, Sangiovese sprayed leaves had lower A than control leaves. Due to different weather conditions the reduction of leaf assimilation rate was variable among the two considered growing seasons, similarly the transpiration rate (E) showed a similar trend in 2013 and 2014 but with different values. Significant differences were found between treated vines and controls. In 2013, E measured at harvest was $6.81 \mathrm{mmol} \mathrm{H}_{2} \mathrm{O} \mathrm{m}^{2} \mathrm{~s}^{-1}$ in the control and $4.23 \mathrm{mmol} \mathrm{H}_{2} \mathrm{O} \mathrm{m}^{2} \mathrm{~s}^{-1}$ in the VG treated Falanghina vines (Figure 3A). 

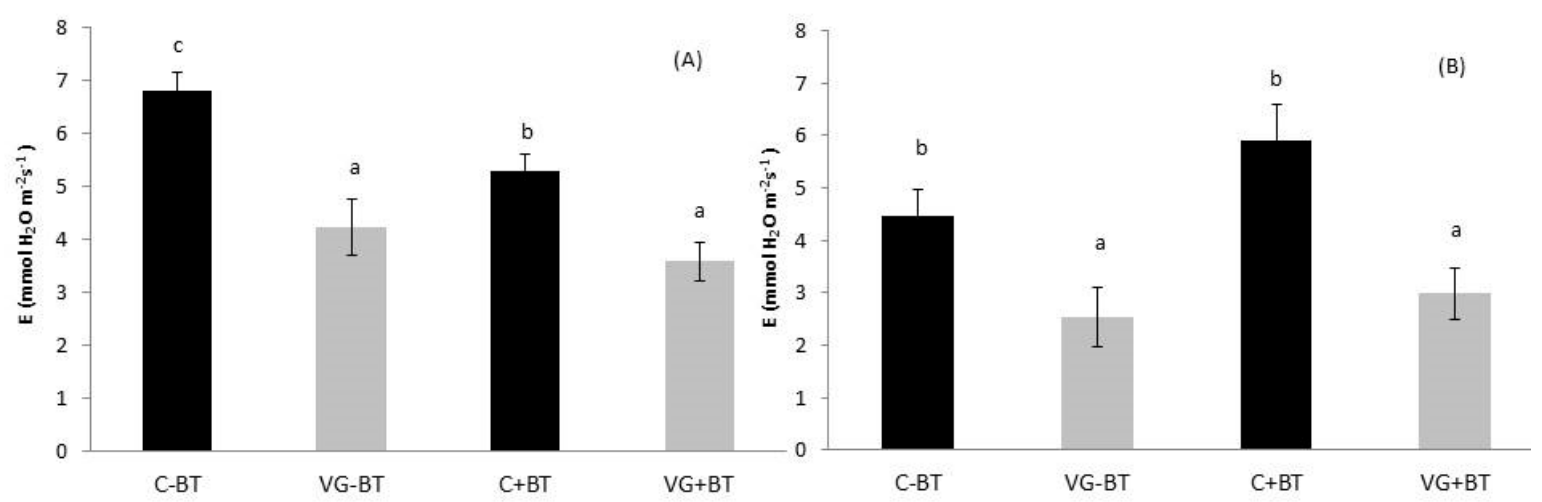

Figure 3. Transpiration rate (E) measured at harvest in the years 2013 (A) and 2014 (B) on fully expanded Falanghina leaves sprayed with anti-transpirant Vapor Gard ${ }^{\circledR}$ (VG) at $\%$ or left unsprayed (C) with or without bunch thinning (BT). Data are averages of 10 replicates \pm SE. Same letter indicates not significant differences at Duncan post hoc test $(p<0.05)$.

The bunch thinning treatment also showed major differences in $\mathrm{E}$ : the $\mathrm{C}+\mathrm{BT}$ was $5.29 \mathrm{mmol}_{2} \mathrm{O}$ $\mathrm{m}^{2} \mathrm{~s}^{-1}$ and the VG + BT $3.58 \mathrm{mmol} \mathrm{H}_{2} \mathrm{O} \mathrm{m}^{2} \mathrm{~s}^{-1}$. Same results with statistically significant differences between treated and control vines were recorded in the year 2014 (Figure 3B). These findings are comparable with others studies of other authors: such as Palliotti et al. [13] that described a reduction of stomatal conductance (gs), A, and E rates following VG spraying accompanied by a marked reduction of substomatal $\mathrm{CO}_{2}$ concentration (182 to $218 \mathrm{ppm}$ in $\mathrm{C}+\mathrm{BT}$ versus 112 to $165 \mathrm{ppm}$ in $\mathrm{VG}+\mathrm{BT}$ ), it is apparent that this behaviour was linked to some physical impairment of stomatal opening and function. The intrinsic water use efficiency (WUEi) derived as the A to gs ratio in all growing seasons is shown in Figure 4. In the 2013 year we observed 119.22 vs. $142.79 \mu \mathrm{mol} \mathrm{mol}^{-1}$ values for VG-BT and C-BT vines respectively, and 127.29 vs. $130.22 \mu \mathrm{mol} \mathrm{mol}^{-1}$ for VG + BT vs. the respective control (Figure 4A).
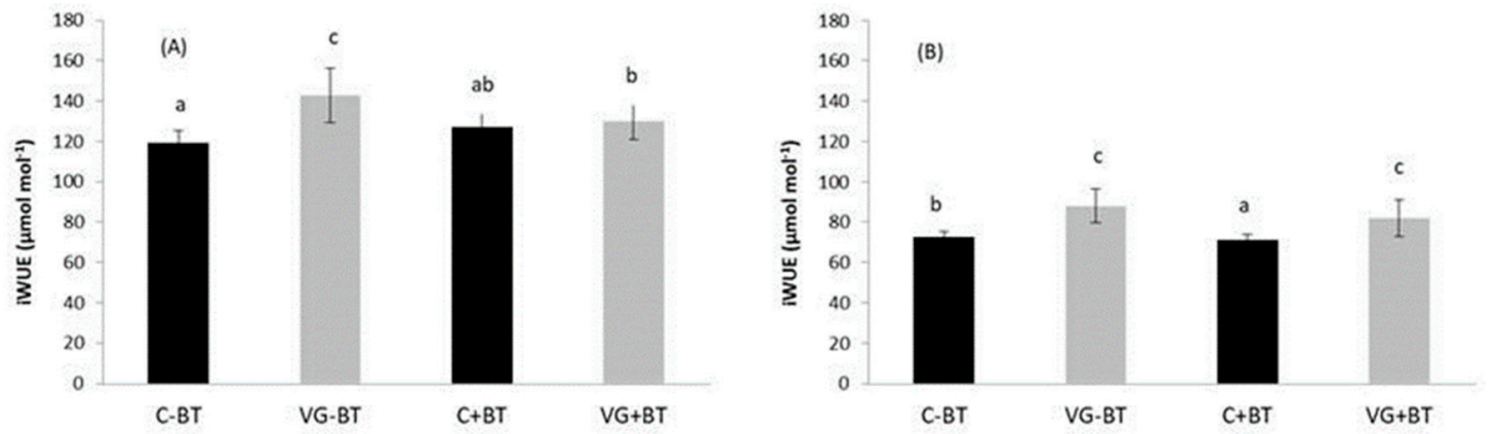

Figure 4. Intrinsic water use efficiency (WUEi) calculated at harvest as A/gs measured in the years 2013 (A) and 2014 (B) on fully expanded Falanghina leaves sprayed with anti-transpirant Vapor Gard ${ }^{\circledR}$ (VG) at $2 \%$ or left unsprayed (C) with or without bunch thinning (BT). Data are averages of 10 replicates \pm SE. Same letter indicates not significant differences at Duncan post hoc test $(p<0.05)$.

The same results were recorded for Falanghina vines in the 2014 growing season (Figure 4B). After the implementation of $\mathrm{VG}$, there was again a reduction of $\mathrm{A}$ and $\mathrm{E}$ rates, showing the effectiveness of VG implementation to quickly decrease stomatal opening. The capacity to accumulate carbon of VG-treated leaves was afterwards limited for a period of four weeks before harvesting, when gs merged again to the levels registered in $C$ leaves. Contrariwise, at harvest, sprayed leaves showed less $\mathrm{E}$ in comparison with control leaves. The recess of $\mathrm{E}$ after VG was implemented brought to a relevant heightening of WUEi in VG relative to $C$ vines and lasted similarly, suggesting a lower water loss in VG relative to $C$ vines, whereas both of them reached achieved almost the same carbon level, 
according to that reported in the literature $[18,30]$. The significant differences identified among the two growing seasons especially in terms of stomatal conductance must be correlated with the lasting of the treatment and its effect, which indeed depend on the weather, referring in particular to rainfalls after the product has been applied. Di Vaio et al. [22] reported the trend of average monthly temperatures and rainfalls recorded in the same farm in Guardia Sanframondi during the same growing seasons. Their results showed similar temperatures but evident differences in terms of rainfalls between 2013 and 2014. Given that, it is possible to attribute the partly incongruous results to the copious rainfalls of summertime 2014 (particularly on the months of June and July). As such, the precipitations happening shortly after the application of the treatment might have affected the lasting of the product on the canopy, hence effecting its overall effectiveness.

\subsection{Yield and Grape Composition}

Data concerning the components of the yield and the structure of the grape at harvest are displayed in Table 1.

Table 1. Yield components, juice and wine composition of Falanghina samples treated with Vapor Gard (VG) and/or bunch thinned (BT) and of the relative controls (C). Values have been collected during two growing seasons, 2013 and 2014. Data are averages of 10 replicates for yield and number of bunches per vine and averages of 4 repetitions for other parameters. For each parameter and for each year, row values with the same letter are not significantly different by Duncan's post hoc test $(p<0.05)$.

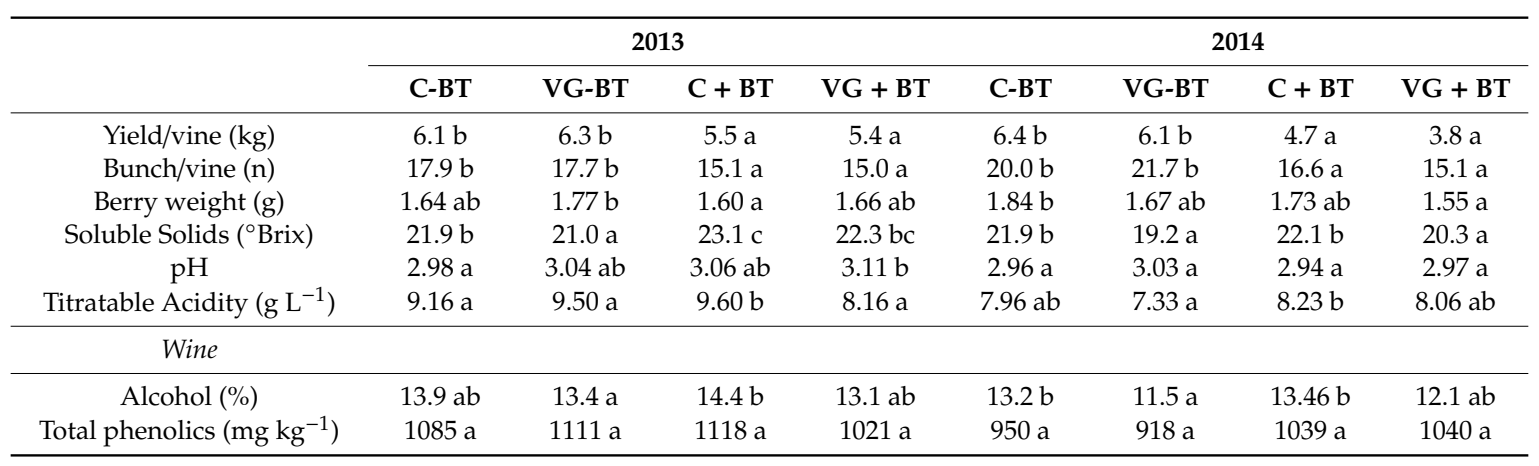

Yield and bunch number per vine were not significantly different between di 1-p-menthene treated vines and controls, while bunch-thinned vines had lower yield and lower bunch number per vine than controls, as expected. In various species, after kaolin application, was observed an increase of yield, and a sunburn reduction [20,31,32]. Different studies on apples point to the effectiveness of kaolin in decreasing the stress caused by the environmental conditions and showed a relation between the increase of the yield and the temperature during growing season [31]. Concerning berry weight, there were no relevant discrepancies when analysing treatments and controls. Interestingly, VG treatment was found to be effective for the objective it was aimed for, which was to reduce sugar accumulation in berries.

In both years, indeed, VG treated grapes showed the lowest sugar content at harvest, with a difference of 0.9 and $2.7^{\circ}$ Brix compared with the control in 2013 and 2014, respectively (Table 1 and Figure 5). The lower accumulation of sugars in the berries, between the theses treated with VG and not, is evident from the 15th day after the treatment in 2014 and in 2013 (Figure 5A,B). In 2013, bunch trimming determined an increase of TSS $\left(+1.2^{\circ}\right.$ Brix respect to the control), while in 2014 it did not determine significant differences. Similarly, $\mathrm{pH}$ and titratable acidity, which are important metabolic and qualitative parameters [33-35], did not show significant differences among treatments in both years. 

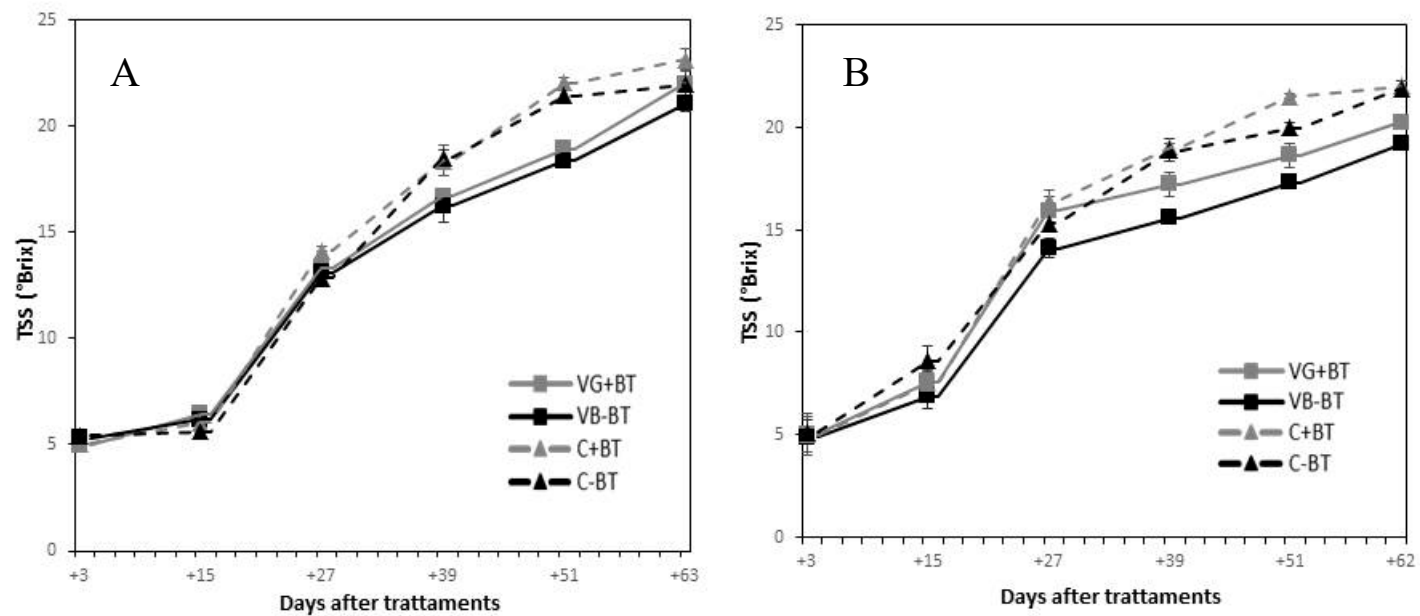

Figure 5. Total soluble solids (TSS) measured in control (C) and treated (VG = Vapor Gard antitranspirant application; BT $=50 \%$ bunch measured in Falanghina vines in (A) 2013 and (B) 2014. Data are averages of ' 4 ' repetitions $\pm \mathrm{SE}$.

\subsection{Pruning Weight}

There is a relevant decrease in the weight of the pruning, in the VG sprayed Falanghina vines as compared with C vines in both year, 2013 and 2014 (Figure 6A,B).
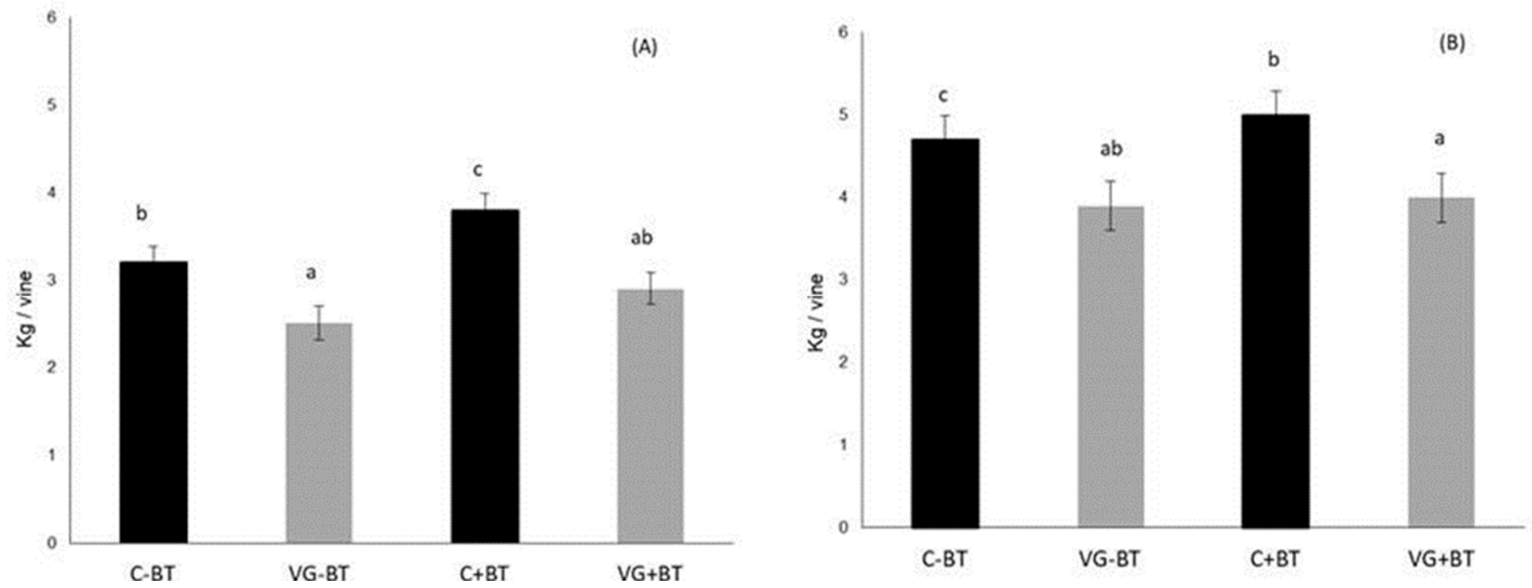

Figure 6. Pruning weight/vine measured in Falanghina vines in 2013 (A) and 2014 (B). Data are averages of 10 replicates \pm SE. Same letter indicates not significant differences at Duncan post hoc test $(p<0.05)$.

In 2013, the weight of the pruning was $3.2 \mathrm{Kg}$ in the control and $2.5 \mathrm{Kg}$ in the VG treated Falanghina vines (Figure 6A). The bunch thinning procedure pointed out other differences: the control $+\mathrm{BT}$ was $3.8 \mathrm{~kg}$ and VG + BT $2.9 \mathrm{~kg}$. In the 2014 were obtained the same data with statistically relevant discrepancies in treated and control vines (Figure 6B). Independently of the bunch thinning the vines treated show a decreased weight of the pruning compared to control. This remarkably indicates how the maturation process was advantaged because the 'vigor' of the vine was inhibited by VG, making it possible to take into consideration to implement this compound in order to control the vigour and at the same time preventing or at least limiting the possibility of a smaller source potential.

\subsection{Wine Composition and Odour Profiles}

In order to evaluate the effects of di-1-p-menthene on wine, grape bunches sampled from treated vines were microvinificated and the obtained wines were analysed in terms of alcoholic strength and odour profiles (Table 1 and Figure 7). 
(A)

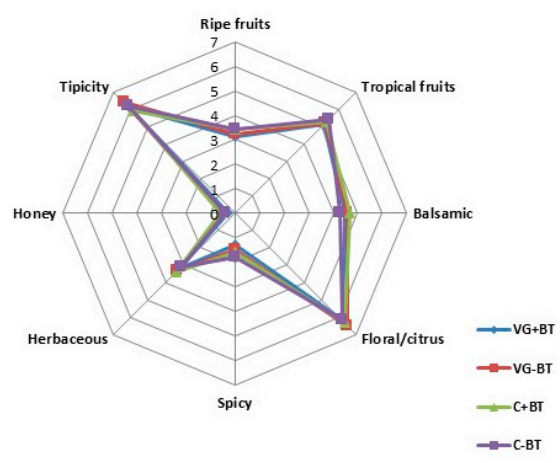

(B)

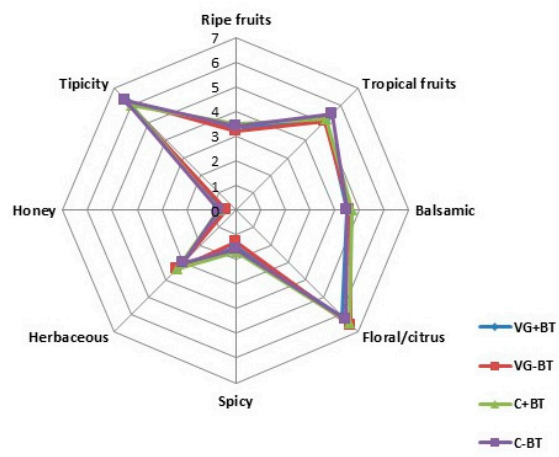

Figure 7. Odour profiles of the Falanghina experimental wines obtained in 2013 (A) and 2014 (B).

According to the lower content in TSS, wines obtained from VG treated grapes had a lower alcohol content. In 2013 , it was $13.9 \%$ v/v vs. $13.4 \% v / v$ in C and VG vines respectively, however, this small difference was not statistically significant (Table 1). Bunch thinning, also when applied in combination with VG treatment, did not determine differences in wine alcohol content. In 2014, the application of VG treatment allowed to obtain a reduction of $1.7 \% v / v$, respect to the control $(11.5 \% v / v$ vs. $13.2 \% v / v$, respectively). Total phenols were not significantly different between control and VG wines, also when bunch thinning was applied. Concerning the wine odour profiles, seven descriptors were consensually generated by the judges: ripe fruits, tropical fruit, balsamic, floral/citrus, spicy, herbaceous and honey. There were no relevant differences when analysing the wines obtained by grapes processed with di-1-p-menthene and untreated grapes. Odour profiles were dominated by tropical fruits and floral/citrus odours, followed by herbaceous, balsamic and ripe fruits notes. This reflects a typical odour profile of Falanghina wine, which present floral and citrus notes given by a considerable content in terpenols [36]. This was confirmed by the score obtained for the typicality judgement, that was over the mean point of the scale for all wines. In conclusion, the application of VG antitraspirant allowed to obtain a reduction in alcohol content, without affecting the odour profile of Falanghina wine. This is a very good result, in terms of preservation of the sensory identity of wine. The application of the organic film-forming di-1-p-menthene-based anti-transpirant, Vapor Gard ${ }^{\circledR}$, on Falanghina post veraison and above the cluster zone can be considered a convenient solution to slow down the maturation in comparison with vines that have not been treated. This technique gave results both in the easiness of implementation and effectiveness to delay the development of sugar in the berries, hence, to produce wines with less alcohol content. At the same time, it proved not to cause damage to essential components such as phenolic compounds, organic acids, or $\mathrm{pH}$ in grape and wines. Furthermore, during the growing seasons taken into consideration in the experiment, di-1-p-menthene proved not to affect either the production or the size of the berries. Implementation of anti-transpirant decreases the stomatal conductance and photosynthetic assimilation rate in Mediterranean climatic conditions. An increase in WUEi was also observed with a consequent improvement of water use efficiency of vines. The di-1-p-menthene treatment should be implemented in order to be effective in decreasing the development of total soluble solids in the berries, at the beginning of veraison and cover the entire stomatal area of the leaf. The effectiveness of the treatment is also dependant on the concentration of the compound, in this study a concentration of $2 \%$ proved to give effective results. It has to be taken into greater consideration the fact that the implementation of this treatment did not cause any variation in the features of the wines made in the two years of the experiment. The olfactory analysis and the wine tasting did not show any worsening of the features or of the characteristic notes in the wines produced during the trial. As such, lowering the sugar content in the berries and, consequently, the alcohol content in the resulting wine, proved not to have damaging effects on the final product, in terms of not worsening its qualitative or quantitative characteristic. 


\section{Conclusions}

Our results showed that the implementation of di-1-p-menthene anti-transpirant at veraison lead to a decrease in stomatal conductance, to a lesser extent, in net photosynthesis and an increase in WUEi. The treatment showed to be an efficient and easy-to-do tool for berry sugar content reduction, in an optic of production of moderate alcohol wines. Concurrently, it had no impact on the base chemical composition of grapes and wines. Moreover, the anti-transpirant treatment of vines did not affect the odour profile of the obtained wines, respect to the untreated control. This a very important feature, in terms of preserving the sensory identity of varietal wines.

Author Contributions: The draft of the manuscript was written by C.V., M.T.L. contributed to data interpretation and manuscript editing, N.M. and A.C. followed the agronomical and physiological measurements. R.D.L. and A.P. were involved in data analysis, data interpretation and writing, C.D.V. coordinated the whole project, provided the intellectual input, set up the experiment and corrected the manuscript. All authors have read and agreed to the published version of the manuscript.

Funding: This research received no external funding.

Conflicts of Interest: The authors declare no conflict of interest.

\section{References}

1. Quirós, M.; Rojas, V.; Gonzalez, R.; Morales, P. Selection of non-Saccharomcyes yeast strains for reducing alcohol levels in wine by sugar respiration. Int. J. Food Microbiol. 2014, 181, 85-89. [CrossRef]

2. Lucchetta, V.; Volta, B.; Tononi, M.; Zanotelli, D.; Andreotti, C. Effects of pre-harvest techniques in the control of berry ripening in grapevine cv. Sauvignon blanc. BIO Web Conf. 2019, 13, 04016. [CrossRef]

3. Silvestroni, O.; Lanari, V.; Lattanzi, T.; Palliotti, A.; Vanderweide, J.; Sabbatini, P. Canopy management strategies to control yield and grape composition of Montepulciano grapevines. Aust. J. Grape Wine Res. 2019, 25, 30-42. [CrossRef]

4. Walker, R.P.; Famiani, F. Organic acids in fruits: Metabolism, functions and contents. Hortic. Rev. 2018, 45, 371-430.

5. Scaglione, G.; Graziani, G.; Federico, R.; Di Vaio, C.; Nadal, M.; Formato, A.; Di Lorenzo, R.; Ritieni, A. Effect of canopy management techniques on the nutritional quality of the Montepulciano grapevine in Puglia (southern Italy). OENO One 2012, 46, 253-261. [CrossRef]

6. Palliotti, A.; Panara, F.; Silvestroni, O.; Lanari, V.; Sabbatini, P.; Howell, G.; Gatti, M.; Poni, S. Influence of mechanical postveraison leaf removal apical to the cluster zone on delay of fruit ripening in Sangiovese (Vitis vinifera L.) grapevines. Aust. J. Grape Wine Res. 2013, 19, 369-377. [CrossRef]

7. Junior, W.J.F.L.; Nadai, C.; Crepalde, L.T.; de Oliveira, V.S.; de Matos, A.D.; Giacomini, A.; Corich, V. Potential use of Starmerella bacillaris as fermentation starter for the production of low-alcohol beverages obtained from unripe grapes. Int. J. Food Microbiol. 2019, 303, 1-8. [CrossRef]

8. Longo, R.; Ristic, R.; Schmidtke, L. Low alcohol wines: Blending with an early harvest or dealcoholisation of a later harvest? Wine Vit. J. 2019, 34, 32-35.

9. Lisanti, M.T.; Gambuti, A.; Genovese, A.; Piombino, P.; Moio, L. Partial dealcoholization of red wines by membrane contactor technique: Effect on sensory characteristics and volatile composition. Food Bioprocess Technol. 2013, 6, 2289-2305. [CrossRef]

10. Schmidtke, L.M.; Blackman, J.W.; Agboola, S.O. Production technologies for reduced alcoholic wines. J. Food Sci. 2012, 77, R25-R41. [CrossRef]

11. Palliotti, A.; Tombesi, S.; Silvestroni, O.; Lanari, V.; Gatti, M.; Poni, S. Changes in vineyard establishment and canopy management urged by earlier climate-related grape ripening: A review. Sci. Hortic. 2014, 178, 43-54. [CrossRef]

12. Filippetti, I.; Allegro, G.; Valentini, G.; Pastore, C.; Poni, S.; Intrieri, C. Effects of mechanical pre-bloom defoliation on cordon de royat pruned Sangiovese (Vitis Vinifera L.) vines. OENO One 2011, 45, 19-25. [CrossRef]

13. Palliotti, A.; Panara, F.; Famiani, F.; Sabbatini, P.; Howell, G.S.; Silvestroni, O.; Poni, S. Postveraison application of antitranspirantdi-1-p-menthene to control sugar accumulation in Sangiovese grape vines. Am. J. Enol. Vitic. 2013, 64, 378-385. [CrossRef] 
14. Intrieri, C.; Allegro, G.; Valentini, G.; Pastore, C.; Colucci, E.; Filippetti, I. Effect of pre-bloom anti-transpirant treatments and leaf removal on "Sangiovese" (Vitis vinifera L.) winegrapes. Vitis J. Grapevine Res. 2013, 52, 117-124.

15. Conde, A.; Pimentel, D.; Neves, A.; Dinis, L.-T.; Bernardo, S.; Correia, C.M.; Gerós, H.; Moutinho Pereira, J. Kaolin foliar application has a stimulatory effect on phenylpropanoid and flavonoid pathways in grape berries. Front. Plant Sci. 2016, 7, 1150. [CrossRef]

16. Abdallah, M.M.S.; El-Bassiouny, H.M.S.; AbouSeeda, M.A. Potential role of kaolin or potassium sulfate as anti-transpirant on improving physiological, biochemical aspects and yield of wheat plants under different watering regimes. Bull. Natl. Res. Cent. 2019, 43, 134. [CrossRef]

17. Rosati, A. Physiological effects of kaolin particle film technology: A review. Funct. Plant Sci. Biotech. 2007, 1, 100-105.

18. Palliotti, A.; Poni, S.; Petoumenou, D.; Vignaroli, S. Effects of modulated limitation of canopy photoassimilation using anti-traspirant on yield and grape composition. In Proceedings of the II Convegno Nazionale di Viticoltura, Marsala, Italia, 14-19 July 2008.

19. Fahey, D.J.; Rogiers, S.Y. Di-1-p-menthene reduces grape leaf and bunch transpiration. Aust. J. Grape Wine Res. 2019, 25, 134-141. [CrossRef]

20. Brillante, L.; Belfiore, N.; Gaiotti, F.; Lovat, L.; Sansone, L.; Poni, S.; Tomasi, D. Comparing kaolin and pinolene to improve sustainable grapevine production during drought. PLoS ONE 2016, 11, e0156631. [CrossRef]

21. Gatti, M.; Galbignani, M.; Garavani, A.; Bernizzoni, F.; Tombesi, S.; Palliotti, A.; Poni, S. Manipulation of ripening via antitranspirants in cv. Barbera (Vitis vinifera L.). Aust. J. Grape Wine Res. 2016, 22, 245-255. [CrossRef]

22. Di Vaio, C.; Marallo, N.; Di Lorenzo, R.; Pisciotta, A. Anti-Transpirant Effects on Vine Physiology, Berry and Wine Composition of cv. Aglianico (Vitis vinifera L.) Grown in South Italy. Agronomy 2019, 9, 244. [CrossRef]

23. Di Meo, F.; Aversano, R.; Diretto, G.; Demurtas, O.C.; Villano, C.; Cozzolino, S.; Filosa, S.; Carputo, C.; Crispi, S. Anti-cancer activity of grape seed semi-polar extracts in human mesothelioma cell lines. J. Funct. Foods 2019, 61, 103515. [CrossRef]

24. De Filippis, F.; A ponte, M.; Piombino, P.; Lisanti, M.T.; Moio, L.; Ercolini, D.; Blaiotta, G. Influence of microbial communities on the chemical and sensory features of Falanghina sweet passito wines. Food Res. Int. 2019, 120, 740-747. [CrossRef]

25. Villano, C.; Rinaldi, A.; Lanzillo, C.; Moio, L.; Tamburrino, A.J.; Carputo, D.; Frusciante, L.; Aversano, R. Polyphenol content and differential expression of flavonoid biosynthetic pathway genes in berries of Aglianico. Acta Hortic. 2017, 1188, 141-148. [CrossRef]

26. Rinaldi, A.; Villano, C.; Lanzillo, C.; Tamburrino, A., Jr.; Jourdes, M.; Teissedre, P.L.; Moio, L.; Frusciante, L.; Carputo, D.; Aversano, R. Metabolic and RNA profiling elucidates proanthocyanidins accumulation in Aglianico grape. Food Chem. 2017, 233, 52-59. [CrossRef]

27. Glories, Y.; Augustin, M. Maturité phénolique du raisin, conséquences technologiques: Application aux millésimes 1991 et 1992. In Proceedings of the Journée technique du CIVB, Bordeaux, France, 21 January 1993; pp. 56-61.

28. Gale, J.; Hagan, R.M. Plant antitranspirants. Annu. Rev. Plant Physiol. 1966, 17, 269-282. [CrossRef]

29. Song, J.; Shellie, K.C.; Wang, H.; Qian, M.C. Influence of deficit irrigation and kaolin particle film on grape composition and volatile compounds in Merlot grape (Vitis vinifera L.). Food Chem. 2012, 134, 841-850. [CrossRef]

30. Tittmann, S.; Stöber, V.; Bischoff-Schaefer, M.; Stoll, M. Application of anti-transpirant under greenhouse conditions of grapevines (Vitis vinifera cv. Riesling and cv. Müller-Thurgau) reduce photosynthesis. Ciênc. Téc. Vitiviníc. 2013, 28, 276-282.

31. Glenn, D.M.; Puterka, G.J.; Drake, S.R.; Unruh, T.R.; Knight, A.L.; Baherle, P.; Prado, E.; Baugher, T.A. Particle film application influences apple leaf physiology, fruit yield, and fruit quality. J. Am. Soc. Hortic. Sci. 2001, 126, 175-181. [CrossRef]

32. Cantore, V.; Pace, B.; Albrizio, R. Kaolin-based particle film technology affects tomato physiology, yield and quality. Environ. Exp. Bot. 2009, 66, 279-288. [CrossRef]

33. Famiani, F.; Battistelli, A.; Moscatello, S.; Cruz-Castillo, J.G.; Walker, R.P. The organic acids that are accumulated in the flesh of fruits: Occurrence, metabolism and factors affecting their contents-A review. Rev. Chapingo Ser. Hortic. 2015, 21, 97-128. [CrossRef] 
34. Famiani, F.; Farinelli, D.; Moscatello, S.; Battistelli, A.; Leegood, R.C.; Walker, R.P. The contribution of stored malate and citrate to the substrate requirements of metabolism of ripening peach (Prunus persica L. Batsch) flesh is negligible. Implications for the occurrence of phosphoenolpyruvate carboxykinase and gluconeogenesis. Plant Physiol. Biochem. 2016, 101, 33-42. [CrossRef]

35. Walker, R.P.; Battistelli, B.; Moscatello, S.; Técsi, L.; Leegood, R.C.; Famiani, F. Phosphoenolpyruvate carboxykinase and gluconeogenesis in grape pericarp. Plant Physiol. Biochem. 2015, 97, 62-69. [CrossRef]

36. Piombino, P.; Genovese, A.; Gambuti, A.; Lamorte, S.A.; Lisanti, M.T.; Moio, L. Effects of off-vine bunches shading and cryomaceration on free and glycosylated flavours of Malvasia delle Lipari wine. Int. J. Food Sci. Tech. 2010, 45, 234-244. [CrossRef]

(C) 2020 by the authors. Licensee MDPI, Basel, Switzerland. This article is an open access article distributed under the terms and conditions of the Creative Commons Attribution (CC BY) license (http://creativecommons.org/licenses/by/4.0/). 